\title{
Positive Correlation between Very Small Embryonic Stem Cell, Hematopoietic Stem Cell, and Endothelial Progenitor Cell in Umbilical Cord Blood Unit
}

\author{
Angliana Chouw ${ }^{1,2, *}$, Bayu Winata Putera ${ }^{2}$, Cynthia Retna Sartika $^{2}$, Ajeng Diantini $^{1}$ \\ ${ }^{1}$ Faculty of Pharmacy, Universitas Padjadjaran, Jl. Eijkman No. 38, Bandung, Indonesia \\ ${ }^{2}$ Prodia Stem Cell Indonesia, Jl. Kramat VII No. 11, Jakarta, Indonesia \\ *Corresponding author. E-mail: angliana@prostem.co.id
}

Received date: Apr 21, 2018; Revised date: Jul 5, 2017; Accepted date: Jul 6, 2018

\section{Abstract}

2 ACKGROUND: Umbilical Cord Blood (UCB) has been widely use as regenerative medicine due to the content of undifferentiated cell which have capability to do self-renewal and differentiation into various type of cell called stem cells. Recent studies show that UCB contains not only hematopoietic stem cell (HSC) but also others stem cell and progenitor cell such as endothelial progenitor cell (EPC) and very small embryonic-like stem cell (VSEL). It is beliefs that HSC and EPC shared the same progenitor. In this study, correlation between the cell number of HSC, EPC and VSEL is analyzed in umbilical cord blood as the source of stem cell for clinical application.

METHODS: The cell number of HSC, EPC and VSEL is counted from cryopreserved UCB collected from 22 women delivered via cesarean section which already stored for more than 2 years in this study. Sample were incubated with antibodies such as cluster of differentiation (CD)34phycoerythrin (PE)/CD45-fluorescein isothiocyanate
(FITC), CD133/1 (anti-CD (AC)133)-antigen-presenting cell (APC) and, CD184 (C-X-C chemokine receptor (CXCR)4)-PE.Vio770 to detect the present of HSC, EPC and VSEL in UCB. Sample were analyze using flowcytometer BD FACS Canto II.

RESULTS: The cell population of HSC and late-EPC is $0.009 \%$ and $0.01 \%$ of total cell in UCB. VSEL only represented $0.001 \%$ from total cell in UCB, showing the lowest number of cell population in UCB. The correlation between the cell number of HSC and EPC is $\mathrm{r}=0,483^{*}, p=0.023$ ) and between HSC and VSEL is $\mathrm{r}=0.510^{*}, p=0.015$.

CONCLUSION: In this study, both EPC and VSEL have a significant positive correlation with HSC.

KEYWORDS: stem cell, umbilical cord blood, endothelial progenitor, flowcytometry

Indones Biomed J. 2018; 10(3): 231-5

\section{Introduction}

Vascular repair and endothelial restoration in atherosclerotic disease affected with endothelial progenitor cells (EPC). However, isolating EPC from pheripheral bloods remain difficult as they are a very rare population of cells.(1) The alternative source of EPC are bone marrow and umbilical cord blood. Umbilical Cord Blood (UCB) has been widely use as regenerative medicine due to the content of hematopoietic stem cell (HSC).(2) Moreover, UCB also served as the source of undifferentiated cell which have capability to do self-renewal and differentiation into various type of cell called stem cells.(3) Stem cells are defined as cell that have the ability to self-renew and to differentiate into specialized cell.(4) Stem cell population in UCB have multipotent characteristic, which are able to differentiate into various type of cell.(5) Every type of stem cell has a different function in regenerative medicine therapy.(6) Recent studies show that UCB 
contains not only HSC but also others stem cell and progenitor cell. Cell such as endothelial progenitor cell (EPC) and very small embryonic-like stem cell (VSEL) are found in UCB.(7)

Hematopoeitic and vascular endothelial progenitor cell share the same antigens expression on cell surface marker.(8) The function of the both cell were differentiate such as HSC is to form blood cells and EPC is to form blood vessels.(9) Human endothelial progenitor cells firstly found as circulationg cell that is use to promote the vasculogenesis in repairing the blood vessel. $(8,10)$ Neovascularization is an important process for tissue repair and regeneration.(9) In the process of neovascularization, EPC will differentiate into endothelial cells to repair the injured tissue. EPC will also secrets growth factors to induce the activation of endogenous stem cell in human body.(11)

Others stem cell found in UCB is VSEL, a pluripotent cell which have potency to differentiate and plays role in tissue regeneration and repair.(12) VSEL expressed CXCR4+ antigen cell surface marker and significantly smaller than HSC.(13) According to Guerin, et al., VSEL show the capability to differentiate into endothelial cell when mobilized into critcal limb ischemic patient. (14) Such abilities to differentiate into many types of cell is decribed by Ratajczak, et al., show that VSEL have pluripotency capacity which is important in cell regenrative and therapy.(15)

When transplanted due to injury, UCB-derived cells shown to contribute in the tissue regeneration of skeletal muscle, neural, and myocardial.(16) Thus makes stem cell as a promising treatment to cure the incurable diseases. $(17,18)$ Those function makes UCB as an important source of stem cell. In this study, correlation of the cell number between HSC, EPC and VSEL was analyzed in umbilical cord blood as the source of stem cell for clinical application, especially for cardiac and neurologiacal disorder.

\section{Methods}

This study is conducted in Prodia Stem Cell Laboratory after received ethical clearence No. 1001/UN6/C10/PN/2017 from Health Research Ethic Committee Medical Faculty Padjajaran University.

\section{Cell Staining and Flowcytometry Detection}

Cryopreserved UCB which already stored for more than 2 years were thawed in $37^{\circ} \mathrm{C}$. Antibodies such as cluster of differentiation (CD)34-phycoerythrin (PE)/CD45fluorescein isothiocyanate (FITC) (BD Bioscience, San Jose, CA, USA), CD133/1 (anti-CD (AC)133)-antigenpresenting cell (APC) (Miltenyi Biotec $\mathrm{GmbH}$, Bergish, Germany), CD184 (C-X-C chemokine receptor (CXCR)4)PE.Vio770 (Miltenyi Biotec $\mathrm{GmbH}$ ) were add to each samples in a BD Trucount tube (BD Bioscience). Sample were incubated for 30 minutes in dark. BD FACS Lysing Solution 1x (BD Bioscience) were added to each sample tube and incubated for 10 minutes. All sample were run in BD FACS Canto II.

\section{Cell Number Count}

Cell number were counted as decribed in manul instruction for BD Trucount tube to get cell number $/ \mathrm{mL}$.

\section{Results}

\section{Sample Profile}

UCB were collected from from 22 women delivered via cesarean section. Gestation age is over 36 weeks.

\section{HSC, EPC, and VSEL number in UCB}

Calculated cell number is conducted from event counted in flowcytometry with gating strategy for HSC, EPC, and VSEL (Figure 1). HSC represented antibody marker CD34+ and CD45 dim. Population of EPC showed by antibody marker CD45, $\mathrm{CD}^{+} 4^{+}$and $\mathrm{CD} 133^{+}$. VSEL is detected using antibody marker CD45- and CD184(CXCR4) ${ }^{+}$.

Cell number counted in UCB show that late-EPC have the highest concentration compare to HSC dan VSEL (Tabel 1). The proportion of HSC and late-EPC is $0.009 \%$ and $0.01 \%$ of the total population of cell in UCB. VSEL only represented $0.001 \%$ from total cell in UCB, showing the lowest number of cell population in UCB.

Table 1. Cell Number in UCB.

\begin{tabular}{lccc}
\hline & $\begin{array}{r}\text { Mean } \\
(\mathbf{n}=\mathbf{2 2})\end{array}$ & SD & $\begin{array}{c}\text { Proportion } \\
(\mathbf{\%})\end{array}$ \\
\hline HSC $\left(\mathbf{1 0}^{\mathbf{3}}\right.$ cell $\left./ \mathbf{m L}\right)$ & 35.62 & 34.903 & $0.01 \%$ \\
Late- EPC $\left(\mathbf{1 0}^{3}\right.$ cell $\left./ \mathbf{m L}\right)$ & 54.38 & 70.402 & $0.01 \%$ \\
VSEL $\left(\mathbf{1 0}^{3}\right.$ cell $\left./ \mathbf{m L}\right)$ & 5.04 & 5.775 & $0.00 \%$ \\
\hline
\end{tabular}

\section{Correlation between HSC and EPC and VSEL in UCB}

Correlation test using Spearman Correlation test show that in Tabel 2. EPC and VSEL have significant positive correlation with HSC. 


\section{A. Hematopoietic Stem Cells $\left(\mathrm{CD}^{\mathrm{dim}} / \mathrm{CD34}^{+}\right)$}
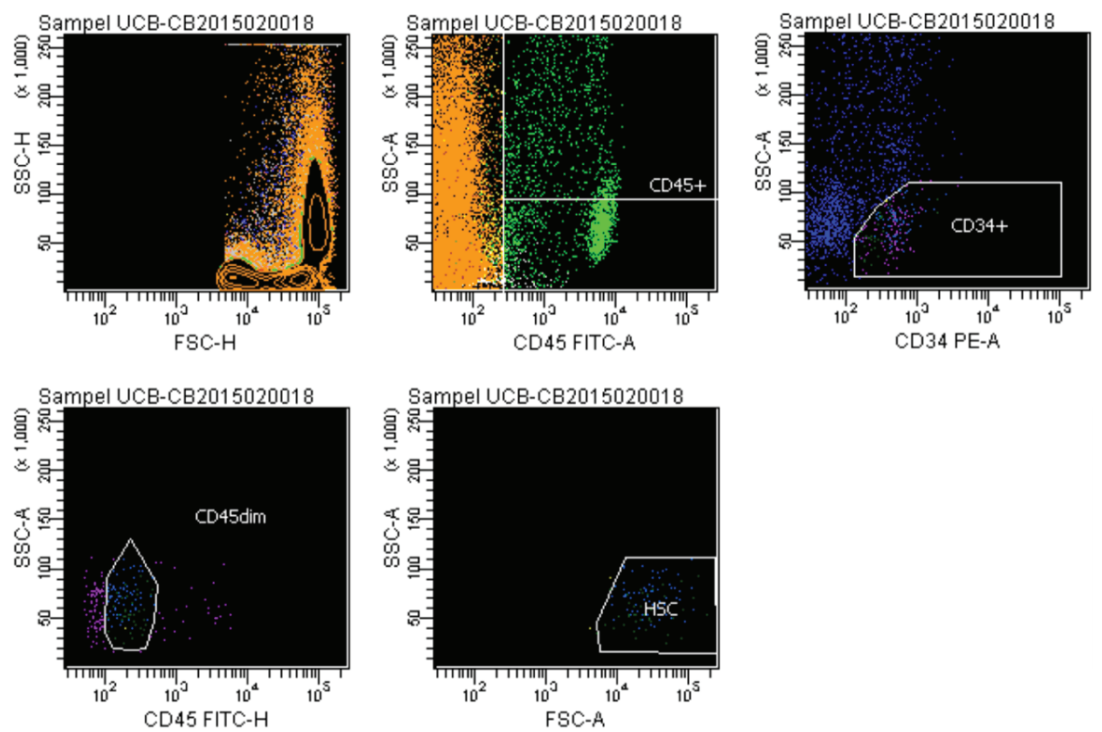

\section{B. Late EPC $\left(\mathrm{CD}^{2} / \mathrm{CD}^{+} 4^{+} / \mathrm{CD}^{2} 3^{+}\right)$}
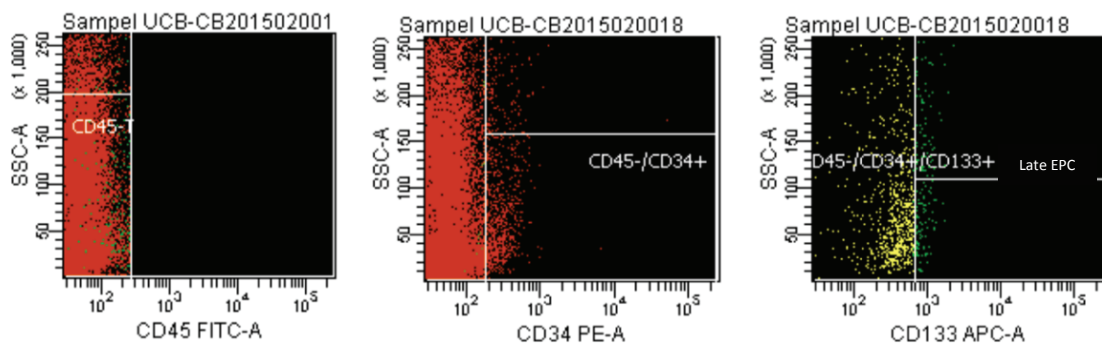

\section{VSEL $\left(\mathrm{CXCR}^{+} / \mathrm{CD} 45^{-}\right)$}
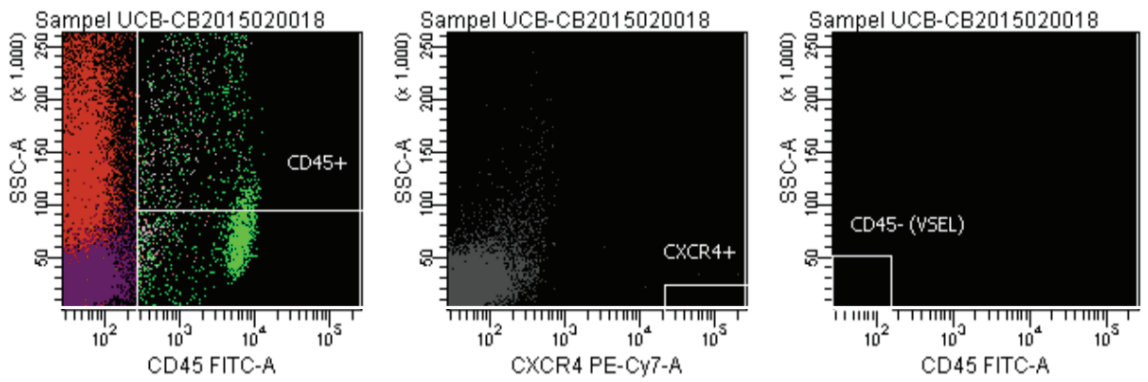

Figure 1. Gating strategies for HSC, late-EPC and VSEL. A: HSC using CD45-FITC and CD34-PE; B: Late-EPC using CD45-FITC, CD34-PE and CD133-APC; C: VSEL using CD45-FITC and CXCR4-PE.Vio770.

\section{Discussion}

\section{Cell Number of HSC, EPC and VSEL in UCB}

Umbilical cord blood already known as source of HSC. It was reported in previous study that HSC under the expression of $\mathrm{CD}_{3} 4^{+}$found in $\mathrm{UCB}$ is $0.02-1.43 \%$ of the total cell population.(19) In this study, the number of HSC under the expresion of CD $34^{+}$and $\mathrm{CD} 45^{-}$is $0.009 \%$, slightly lower than the reference number.
Late-EPC detected in this study show the highest number of cell population in UCB. This might due to the differentiation of the early-EPC into late-EPC. Regulation of angiogenesis is depending on the biological properties of EPC. The finding of higher late-EPC number in UCB show that UCB have more potency to be used as regenerative medicine for cascular repair and endothelial restoration. Late-EPC show to have more proliferation and angiogenesis genes which is used for the neovascularization compare to early-EPC.(20) Very small embryonic-like stem cell show 
Table 2. Correlation between HSC and other cell in UCB. $(\mathrm{n}=22)$

\begin{tabular}{ccc}
\hline & EPC & VSEL \\
\hline \multirow{2}{*}{ HSC } & $\mathrm{r}=0.483^{*}$ & $\mathrm{r}=0.510^{*}$ \\
& $p=0.023$ & $p=0.015$ \\
\hline
\end{tabular}

Note: *significant $p<0.005$, r: coeficient correlation

to have the lowest number compare to the others cell in UCB. VSEL are a small cell which are smaller than HSC (21) that express CXCR4, CD34, and CD133 surface marker.(13) Isolation of VSEL from UCB by Hasala, et al., show that the population of VSEL is less than $0.2 \%$.(22)

\section{Correlation between Hematopoietic Stem Cell and Late- Endothelial Progenitor Cell}

Positive correlation $\left(\mathrm{r}=0.483^{*}, p=0.023\right)$ show between the cell number of HSC and EPC. Hemangioblast, a common mesodermal precursor is believed as the cellular origin of HSC and EPC. $(23,24)$ Hemagioblast is a bi-potent progenitor that could give rise to angioblast and hematopoiesis.(25) This idea came from the evidence of blood islands structure which are a layer of endothelial cell which surrounded the first blood cell.(26)

There is a theory that believe that the HSC will differentiate into hematopoietic progenitor cell and will produce EPC. EPC then differentiated into endothelial cells which will built the new blood formation called vasculogenesis or form a new capillaries from pre-exiting vessel called angiogenesis.(1,27). Both of the process need EPC which directly form new and provide growth factor needed for the process.(27) EPC have function to do vascular repairment and repairing endothel dysfunction by replacing the damage cell.(24)

\section{Correlation between Hematopoietic Stem Cell and Very Small Embryonic-like Stem Cell}

VSEL is believe as an envision from the germ lineage of epiblast derived cell that deposited in early gastrulation or embryogenesis. This origin causes the VSEL to express several pluripotent markers characteristic.(12,21) Hematopoietic stem cell shows to have positive correlation with VSEL $\left(\mathrm{r}=0.510^{*}, p=0.015\right)$. This correlation might because the ability of VSEL to give rise into long term HSC (LT-HSC), which has the capability to repopulation itself. Naturally, VSEL didn't express CD45 surface marker but when needed VSEL could differentiate into tissue commited stem cell if needed. CD45- VSEL might differentiate into
CD45+ HSC.(12) $\mathrm{CD}^{4} 5^{+} \mathrm{HSC}$ will be the candidate for LTHSC that is use for the renewal of HSC linage in human body.(28)

\section{Conclusion}

Hematopoietic stem cell, endothelial progenitor cell, and very small embryonic stem cell number found in umbilical cord blood show positive correlation between HSC and EPC also between HSC and VSEL.

\section{Acknowledgment}

This research was supported and funded by Prodia Group and Prodia StemCell Indonesia.

\section{References}

1. Tagawa S, Nakanishi C, Mori M, Yoshimuta T, Yoshida S, Shimojima $\mathrm{M}$, et al. Determination of early and late endothelial progenitor cells in peripheral circulation and their clinical association with coronary artery disease. Int J Vasc Med. 2015; 2015: 674213. doi: 10.1155/2015/674213.

2. Meiliana A, Wijaya A. Application of umbilical cord blood stem cells in regenerative medicine. Indones Biomed J. 2014; 6:115-22.

3. Mosca RS. Potential uses of cord blood in cardiac surgery. J Blood Transfus. 2012; 2012: 568132. doi: 10.1155/2012/568132.

4. Weiss ML, Troyer DL. Stem cells in the umbilical cord. Stem Cell Rev. 2006; 2: 155-62.

5. Jaing TH. Umbilical cord blood: a trustworthy source of multipotent stem cells for regenerative medicine. Cell Transplant. 2014; 23: 493-6.

6. Achyut BR, Varma NRS, Arbab AS. Application of umbilical cord blood derived stem cells in diseases of the nervous system. J Stem Cell Res Ther. 2014; 2014; 4: 1000202. doi: 10.4172/21577633.1000202

7. Matsumoto T, Mugishima H. Non-Hematopoietic stem cells in umbilical cord blood. Int J Stem Cells. 2009; 2: 83-9.

8. Yoder MC. Human endothelial progenitor cells. Cold Spring Harb Perspect Med. 2012; 2: a006692. doi: 10.1101/cshperspect. a006692.

9. Watt SM, Athanassopoulos A, Harris AL, Tsaknakis G. Human endothelial stem/progenitor cells, angiogenic factors and vascular repair. J R Soc Interface. 2010; 7(Suppl 6): S731-51.

10. Sandra F, Oktaviono YH, Widodo MA, Dirgantara Y, Chouw A, Sargowo D. Endothelial progenitor cells proliferated via MEKdependent p42 MAPK signaling pathway. Mol Cell Biochem. 2015; 400: 201-6.

11. Kamei N, Atesok K, Ochi M. The use of endothelial progenitor cells for the regeneration of musculoskeletal and neural tissues. Stem Cells Int. 2017; 2017: 1960804. doi: 10.1155/2017/1960804.

12. Ratajczak MZ, Zuba-Surma EK, Ratajczak J, Wysoczynski M, Kucia M. Very small embryonic like (VSEL) stem cells - characterization, 
developmental origin and biological significance. Exp Hematol. 2008; 36: 742-51.

13. Danova-Alt R, Heider A, Egger D, Cross M, Alt R. Very small embryonic-like stem cells purified from umbilical cord blood lack stem cell characteristics. PLoS ONE. 2012; 7: e34899. doi: 10.1371/ journal.pone.0034899.

14. Guerin CL, Loyer X, Vilar J, Cras A, Mirault T, Gaussem P, et al. Bone-marrow-derived very small embryonic-like stem cells in patients with critical leg ischaemia: evidence of vasculogenic potential. Thromb Haemost. 2015; 113: 1084-94.

15. Ratajczak MZ, Ratajczak J, Suszynska M, Miller DM, Kucia M, Shin D-M. A novel view of the adult stem cell compartment from the perspective of a quiescent population of very small embryonic-like stem cells. Circ Res. 2017; 120: 166-78.

16. Zuba-Surma EK, Klich I, Greco N, Laughlin MJ, Ratajczak J, Ratajczak MZ. Optimization of isolation and further characterization of umbilical cord blood-derived very small embryonic/ epiblast-like stem cells (VSELs): Umbilical cord blood-derived VSELs. Eur J Haematol. 2010; 84: 34-46.

17. Lane SW, Williams DA, Watt FM. Modulating the stem cell niche for tissue regeneration. Nat Biotechnol. 2014; 32: 795-803.

18. Damayanti S, Triana R, Chouw A, Dewi NM. Is stem cell a curer or an obstruction? Mol Cell Biomed Sci. 2017; 1: 17-27

19. Hordyjewska A, Popiołek $€$, Horecka A. Characteristics of hematopoietic stem cells of umbilical cord blood. Cytotechnology. 2015; 67: 387-96.

20. Cheng CC, Chang SJ, Chueh YN, Huang TS, Huang PH, Cheng $\mathrm{SM}$, et al. Distinct angiogenesis roles and surface markers of early and late endothelial progenitor cells revealed by functional group analyses. BMC Genomics. 2013; 14: 182. doi: 10.1186/1471-216414-182.

21. Lu R, Miao D. Very small embryonic like (VSEL) stem cells. J Nanjing Med Univ. 2008; 22: 265-8.

22. Halasa M, Baskiewicz-Masiuk M, Dabkowska E, Machalinski B. An efficient two-step method to purify very small embryoniclike (VSEL) stem cells from umbilical cord blood (UCB). Folia Histochem Cytobiol. 2008; 46: 239-43.

23. Jaffredo T, Nottingham W, Liddiard K, Bollerot K, Pouget C, Bruijn M de. From hemangioblast to hematopoietic stem cell: An endothelial connection? Exp Hematol. 2005; 33: 1029-40.

24. Thijssen DHJ, Vos JB, Verseyden C, van Zonneveld AJ, Smits P, Sweep FCGJ, et al. Haematopoietic stem cells and endothelial progenitor cells in healthy men: effect of aging and training. Aging Cell. 2006; 5: 495-503.

25. Chen T, Wang F, Wu M, Wang ZZ. Development of hematopoietic stem and progenitor cells from human pluripotent stem cells. J Cell Biochem. 2015; 116: 1179-89.

26. Boisset JC, Robin C. On the origin of hematopoietic stem cells: Progress and controversy. Stem Cell Res. 2012; 8: 1-13. doi: 10.1016/j.scr.2011.07.002

27. Tamma R, Ribatti D. Bone niches, hematopoietic stem cells, and vessel formation. Int J Mol Sci. 2017; 18: 151. doi: 10.3390/ ijms18010151.

28. Liu L, Papa EF, Dooner MS, Machan JT, Johnson KW, Goldberg LR, et al. Homing and long-term engraftment of long- and short-term renewal hematopoietic stem cells. PloS One. 2012; 7(2): e31300. 10.1371/journal.pone.0031300. 